J. Perinall. Med. $14(1986) 109$

\title{
Affinity of tocolytic agents on human placental and myometrial beta- adrenergic receptors
}

\author{
George Falkay and László Kováes
}

Department of Obstetrics and Gynecology, WHO Collaborative Centre in Clinical Research on Human Reproduction, University Medical School of Szeged, Hungary

\section{Introduction}

Initial arrest of premature labor may be successfully achieved by a variety of tocolytic agents. At present beta-adrenergic agonists are the most useful clinical agents to prevent or reduce uterine activity [6]. Beta-adrenergic stimulation decreases frequency and intensity of uterine contractions. In the past few years, successful labelling of receptors by radiolabelled agonists or antagonists has enabled the study of beta-adrenoreceptors in many tissues from several mammalian species. It has recently been shown that the beta-adrenergic ligand $\left[{ }^{3} \mathrm{H}\right]$-dihydroalprenolol (DHA) is able to label binding sites in human term placenta [7] and myometrium [5]. We have previously demonstrated betaadrenergic receptors in early human placenta [3]. The binding properties of beta-adrenoreceptors allow a first evaluation of the pharmacological properties of the ligand under study.

The data reported herein represent the displacement of $\left[{ }^{3} \mathrm{H}\right]$-DHA binding from human myometrial and placental membranes by tocolytic agents which are used in clinical practice or could be used in the future.

\section{Materials and methods}

Human myometrial strips were obtained from uteri at the time of cesarean section. Term

\section{Curriculum vitae}

G. Falkay, Ph.D. Was born in Szeged in 1943 and was graduated in pharmacy' from the University Medical School in Szeged in 1967. Since 1970 he has been working in the Department of Obstetrics and Gynecology, Medical University of Szeged. 1975: WHO fellowship at the Reproductive Endocinology'

Research Unit, Karolinska sjukhnuset, Stockholm. Current studies: biological role of adrenergic receptors in liuman pregnant uterus and feto-placental unit.

placentas were obtained immediately after delivery.

(-) $\left[{ }^{3} \mathrm{H}\right]$-Dihydroalprenolol, specific activity $74.17 \mathrm{Ci} / \mathrm{mmol}$ was purchased from Radiochemical Centre Amersham, England. The following drugs were provided by pharmaceutical companies: clenbuterol, orciprenaline, fenoterol (Boehringer Pharmaccutical Co., Ingelheim), ritodrine, isoxsuprine (Duphar B. V. Amsterdam), terbutaline (Richter G. Pharmaceutical Co., Hungary). Other reagents were commercially available.

Details of the procedure and complete evaluation of the beta-adrenergic receptor assily have 
been published [3]. The tissues were homogenized in 10 volume of buffer containing $10 \mathrm{mM}$ Tris. $\mathrm{HCl} 0.25 \mathrm{M}$ sucrose, $1 \mathrm{mM}$ EDTA and $3 \mathrm{mM} \mathrm{MgCl}_{2}, \mathrm{pH} 7.4$, using an Ultra-Turrax homogenizer. The homogenate was passed through four layers of gauze and centrifuged at $600 \times \mathrm{g}$ for $10 \mathrm{~min}$ at $4^{\circ} \mathrm{C}$ to remove unbroken cells and connective tissue. The supernatant was centrifuged twice at $48000 \times \mathrm{g}$ for $20 \mathrm{~min}$, with washing of the intermediate pellet. The final pellet was resuspended in assay buffer (50 mM Tris. $\mathrm{HCl}, 3 \mathrm{mM} \mathrm{MgCl}$, $\mathrm{pH}$ 7.4). The membrane preparations were stored in liquid nitrogen until used. $100 \mu \mathrm{l}$ aliquots of the membrane fraction were prepared in triplicate and incubated with $6 \mathrm{nM}\left[{ }^{3} \mathrm{H}\right]-\mathrm{DHA}$ and the increasing concentration of the displacing agent in a final volume of $300 \mu$ lassay buffer. After incubation for $20 \mathrm{~min}$ at $25^{\circ} \mathrm{C}, 2 \mathrm{ml}$ of icecold buffer were added and immediately filtered over WhatMaN GF/C glassfiber filters. The filters were washed with $2 \times 5 \mathrm{ml}$ of icecold buffer and counted for ${ }^{3} \mathrm{H}$. Non-specific binding of $\left[{ }^{3} \mathrm{H}\right]-\mathrm{DHA}$ was defined as radioactivity bound to membranes which is not displaced by a high concentration of $( \pm)$ propranolol $(10 \mu \mathrm{M})$. Specific binding is defined as total radioactivity minus non-specific binding.

The experimental data given in table I and in the figures $1 \mathrm{a}$ and $\mathrm{b}$ are means of triplicate determinations in at least two experiments with a S. E. M. < 5\%. HILl plots were calculated by plotting the data as $\ln \left(\frac{B}{B_{o}-B}\right)$ vs. $\log _{10} M$ competing agents. $\mathrm{IC}_{50}$ values for competing drugs were determined by linear regression as the X intercept on a HrLL plot which was determined by least square method. $\mathrm{K}_{\mathrm{i}}$ values were determined by the equation of CHENG and PRUSOFF [2].

$$
\mathrm{K}_{\mathrm{i}}=\frac{\mathrm{IC}_{50}}{\mathrm{~S} / \mathrm{K}_{\mathrm{m}}+1}
$$

where $\mathrm{IC}_{50}$ is the concentration of the competing agent which inhibits ${ }^{3} \mathrm{H}-\mathrm{DHA}$ binding by $50 \%, S$ is the concentration of $\left[{ }^{3} \mathrm{H}\right]-\mathrm{DHA}$ $(6.0 \mathrm{nM})$ in the assay and $\mathrm{K}_{\mathrm{m}}=\mathrm{K}_{\mathrm{D}}$ for $\left[{ }^{3} \mathrm{H}\right]-$ DHA determined from saturation experiment (Placenta $\mathrm{K}_{\mathrm{D}}=2.71 \mathrm{nM}$; Myometrium $\mathrm{K}_{\mathrm{D}}=$ $3.75 \mathrm{nM})$.

\section{Results}

$\left[{ }^{3} \mathrm{H}\right]-\mathrm{DHA}$ binding to human pregnant myometrial and placental membranes were displaced with high affinity by agonists acting at the betaadrenoreceptor (figures $1 \mathrm{a}$ and $\mathrm{b}$ and table $\mathrm{I}$ ). Among the six beta-agonists tested on myometrial preparations, clenbuterol and fenoterol were the most potent while terbutaline was the least. In binding assays on placental preparations clenbuterol was the most potent. The order of potency for other tested agonists was nearly the same as in myometrium.

It is worth noting that clenbuterol is the only compound among the tested drugs in which the phenolic hydroxyl groups are substituted for chlorine. All the agonists showed displacement

Table I. $\mathrm{K}_{\mathrm{i}}$ values (inhibition constants) and HILL coefficients (nH) for betaadrenergic agonists determined from the overall displacement curves of $\left[{ }^{2} \mathrm{H}\right]$-dihydroalprenolol from pregnant human myometrium and placenta.

\begin{tabular}{lllll}
\hline Agonists & $\begin{array}{l}\text { Myometrium } \\
\mathrm{K}_{\mathrm{i}}(\mu \mathrm{M})\end{array}$ & Slope factor $(\mathrm{nH})$ & $\begin{array}{l}\text { Placenta } \\
\mathrm{K}_{\mathrm{i}}(\mu \mathrm{M})\end{array}$ & Slope factor $(\mathrm{nH})$ \\
\hline clenbuterol & 0.7 & 1.64 & 0.06 & 1.78 \\
fenoterol & 1.07 & 1.35 & 2.30 & 1.42 \\
ritodrine & 10.84 & 1.55 & 3.11 & 1.39 \\
isoxsuprine & 13.65 & 1.33 & 3.48 & 1.57 \\
orciprenalin & 38.46 & 1.41 & 4.91 & 1.40 \\
terbutaline & 51.92 & 1.27 & 17.48 & 1.35 \\
\hline
\end{tabular}


(a)

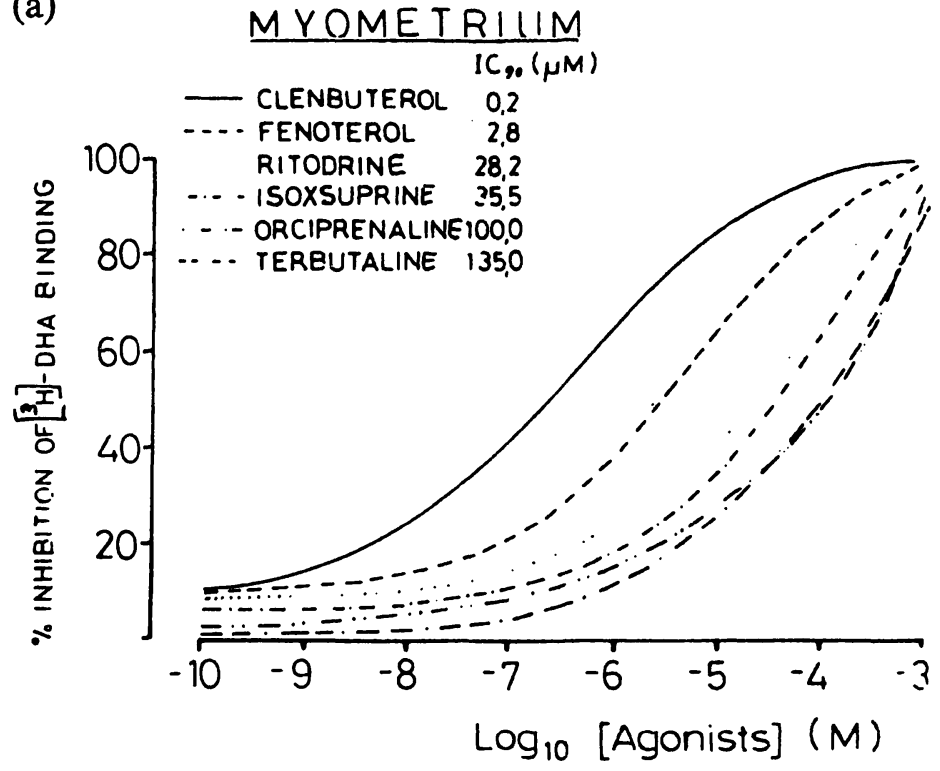

(b)

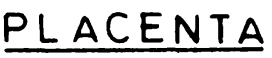

$I C_{50}(\mu \mathrm{M})$

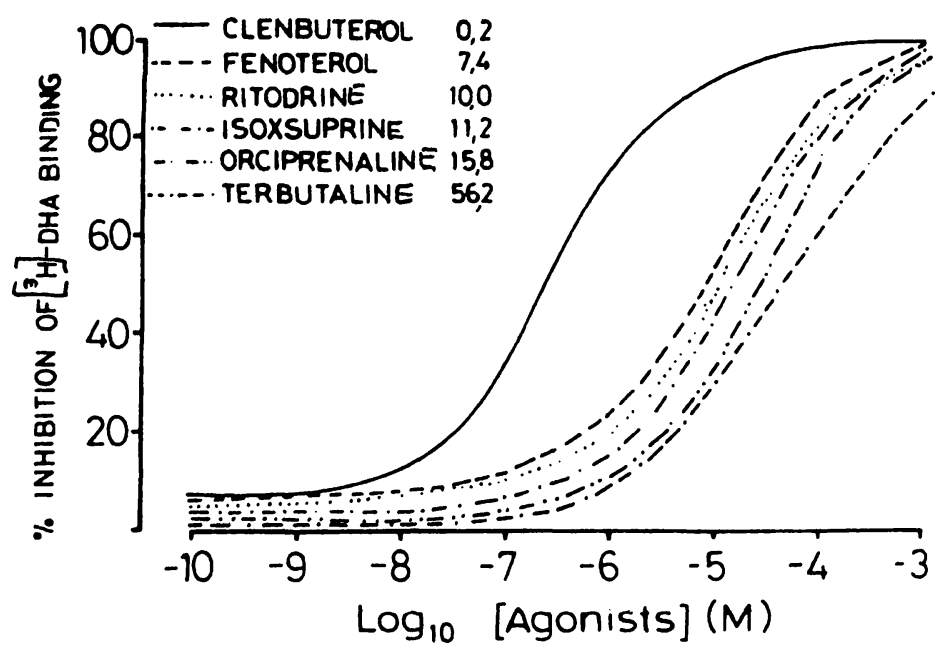

Figure 1. Inhibition of $\left[{ }^{3} \mathrm{H}\right]$-DHA binding by adrenergic agonists in human placental (a) and pregnant myometrial (b) membrane fractions. Membranes were incubated with $6 \mathrm{nM}\left[{ }^{3} \mathrm{H}\right]-\mathrm{DHA}$ in the presence of $9-10$ concentrations of the indicated agents and specific binding was determined as described under "Methods". The percentage of inhibition of specific binding was determined. The concentration of agonist inhibiting $50 \%$ of maximal specific binding of $\left[{ }^{3} \mathrm{H}\right]-\mathrm{DHA}$ is the $\mathrm{IC}_{50}$.

curves with apparent HiLl coefficients (nH) significantly higher than unity $(\mathrm{p}<0.01)$ indicating heterogenity of binding (positive cooperativity). In general, binding of beta-adrenoreceptor agonists was weaker in myometrium than in placenta homogenates.

\section{Conclusions}

In this study we compared the binding of various tocolytic agents to beta-adrenoreceptors in homogenates from human placenta and myometrium.

In a previous investigation [4] we observed that the density of beta-adrenergic receptors in the placenta is much higher than in the myometrium. According to these results we believe that the betamimetic agents may dilate the vascular vessels in the placenta during the treatment of premature labor. This may result in rising of blood-flow and increasing secretion of progesterone as suggested by CARITIS and ZELEZNIK [1]. So it is very likely that the placenta may play an important role in the pharmacological mechanisms of tocolytic agents in inhibitory preterm myometrial activity. Although there is low binding capacity of beta-adrenergic receptors in human pregnant myometrium one has to reckon with a direct effect of tocolytic agents on myometrium.

In our earlier studies [3] the epinephrine, norepinephrine and isoproterenol displacement of $\left[{ }^{3} \mathrm{H}\right]-\mathrm{DHA}$ in placenta membranes were shallow yielding a HiLl coefficient of $0.43-0.53$. The present results show that tocolytic agents give higher HILL coefficients than unity. This discrepancy could be explained by positive cooperativity which is peculiar to the tested drugs. Further investigation is needed to complete understanding of this phenomenon.

A major point of this paper has been to examine the binding properties of clenbuterol. In accordance with pharmacological experiments which proved the substance to be a potent betaadrenoreceptor agonist, clenbuterol binds to human myometrial and placental beta-adrenoreceptors with high potency. 


\section{Summary}

The beta-adrenoreceptor antagonist $\left[{ }^{3} \mathrm{H}\right]$-dihydroalprenolol (DHA) has been used to label adrenoreceptors in membranes from human pregnant myometrium and placenta. Six tocolytic drugs were tested for their ability to bind to the beta-adrenergic receptor of placental and myometrial membranes. Tocolytic agents competed with $\left[{ }^{3} \mathrm{H}\right]-\mathrm{DHA}$ binding in the following order of potency: clenbuterol $>$ fenoterol $>$ ritodrine $>$ isoxsuprine $>$ orciprenaline $>$ terbutaline. All drugs competed for $\left[{ }^{3} \mathrm{H}\right]-\mathrm{DHA}$ binding sites with HILL coefficients greater than unity indicating heterogenity of binding.

In general, binding of beta-adrenoreceptor agonists was weaker in myometrium than in placenta homogenates. According to our results it is very likely that the placenta may play an important role in the pharmacological mechanism of tocolytic agents in inhibitory of premature labor.

Keywords: Beta-adrenoreceptors, myometrium, placenta, tocolytic agents.

\section{Zusammenfassung}

Affinität verschiedener Tokolytika zu betaadrenergen Rezeptoren in der menschlichen Plazenta und im Myometrium

Zur Markierung betaadrenerger Rezeptoren in Membranen von menschlichem Plazentagewebe und Myometrium schwangerer Frauen wurde der betaadrenerge Rezeptorantagonist $\left[{ }^{3} \mathrm{H}\right]$-Dihydroalprenolol (DHA) eingesetzt. Wir testeten sechs verschiedene tokolytische Substanzen bezüglich ihrer Affinität zu betaadrenergen Rezeptoren in Membranen aus Plazenta und Myometrium. Die kompetitive Verdrängung des $\left[{ }^{3} \mathrm{H}\right]-\mathrm{DHA}$ als $\mathrm{Ma} B$ für die Stärke der Affinität zeigte folgende Rangfolge: Clenbuterol $>$ Fenoterol $>$ Ritodrin $>$ Isoxsuprin $>$ Orciprenalin $>$ Terbutalin. Bei allen Substanzen, die kompetitiv $\left[{ }^{3} \mathrm{H}\right]-\mathrm{DHA}$ verdrängten, lagen hohe HILLKoeffizienten vor - ein Hinweis auf die Heterogeintät der Bindung.

Allgemein war die Bindung betaadrenerger Agonisten in Plazentahomogenaten stärker als im Myometrium. Unsere Ergebnisse zeigen, daß die Plazenta eine wichtige Rolle in der Pharmakologie von Tokolytika und damit bei der Hemmung vorzeitiger Wehen spielt.

Schlüsselwörter: Betaadrenerge Rezeptoren, Myometrium, Plazenta, Tokolytika.

\section{Résumé}

Affinité des agents tocolytiques pour les récepteurs bétaadrénergiques du myomètre humain gravide et du placenta

On a utilisé un antagoniste des recepteurs béta-adrénergiques le [3 H]-dihydro-alprenolol (D H A) pour marquer les récepteurs adrénergiques membranaires du myomètre humain gravide et du placenta. On a testé 6 médicaments tocolytiques en raison de leur capacité à se fixer sur les recepteurs béta-adrénergiques des membranes placentaires et myométriales. Les agents tocolytiques ont une affinité compétitive de fixation avec le [3 H]-DHA dans l'ordre suivant: Clembutérol > fénoté- rol $>$ ritodrine $>$ isoxsuprine $>$ orciprénaline $>$ terbutaline. Tous ces médicaments sont compétitifs pour les sites de fixation [ $3 \mathrm{H}]$-DHA avec des coefficients de HILL supérieurs à l'unité ce qui indique l'hétérogenéité de la fixation.

En général la fixation des adréno-récepteurs-béta est plus faible au niveau du myomètre qu'au niveau des homogénats placentaires. Selon nos résultats, il est très probable que le placenta puisse jouer un rôle important dans le mécanisme pharmacologique d'inhibition de l'accouchement prématuré par des agents tocolytiques.

Mots-clés: Adréno-récepteurs-béta, agents tocolytiques, myomètre, placenta.

Acknowledgements: This work was supported by the Scientific Research Council, Ministry of Health, Hungary (01/4-34-446). We are indepted to the Boehringer Pharmaceutical Company Ingelheim for the generous gift of the drugs. 


\section{References}

[1] Caritis, S. N., A. J. ZelezNIK: Effect of adrenergic agonists on progesterone production by human placental cells in culture. Am. J. Obstet. Gynecol. 138 (1980) 677

[2] Cheng, Y. C., W. H. Prusoff: Relationship between the inhibition constant $\left(\mathrm{K}_{\mathrm{i}}\right)$ and the concentration of inhibitor which cases 50 percent inhibition (Iso) of an enzymatic reaction. Biochem. Pharmacol. 22 (1973) 3099

[3] FalKay, G., L. Kovács: Beta adrenergic receptors in early human placenta, characterization of $\left[{ }^{3} \mathrm{H}\right]-$ DHA binding. Life Sci. 32 (1983) 1583

[4] FALKAY, G., L. Kovács: Characterization of betaadrenergic receptors in human myometrium and placenta. Acta Physiol. Acad. Sci. Hung. 65 (1985) 491

[5] Hayashida, D. N., R. Lung, A. Goldfien, J. M. ROBERTS: Human myometrial adrenergic receptors: Identification of the beta-adrenergic receptor by $\left[{ }^{3} \mathrm{H}\right.$ )-dihydroalprenolol binding. Am J. Obstet. Gynecol. 4 (1982) 389

[6] JUNG, H., G. LAMBeRT (eds.): Betamimetic drugs in Obstetrics and Perinatology. Thieme Verlag, Stuttgart, New York 1982

[7] Whitsett, J. A., C. L. Johnson, A. Noguch, C. D. Beckerman, M. Costello: Beta-adrenergic receptors and catecholamine-sensitive adenylate cyclase of the human placenta. J. Clin. Endocrinol. Metab. 50 (1980) 27

Received December 14, 1984. Revised April 9, 1985. Accepted May 6, 1985.

Dr. George Falkay

Dept. of Obstet. and Gynecol.

Univ. Med. School

H-6725 Szeged, Semmelweis u. 1. Hungary 